Proceedings

\title{
Home Range Patterns of the Strictly Protected Caspian Whipsnake (Dolichophis caspius, Gmelin, 1789): A Peri-Urban Population in Vöröskővár, Hungary ${ }^{\dagger}$
}

\author{
Thabang Rainett Teffo ${ }^{1, *}$, Bálint Halpern ${ }^{2}$ and Krisztián Katona ${ }^{1}$ \\ 1 Department of Wildlife Biology H-2100, Institute for Wildlife Management and Nature Conservation, \\ Hungarian University of Agriculture and Life Sciences, Páter Károly street 1, Gödöllő, Hungary; \\ e-mail@e-mail.com \\ 2 MME BirdLife Hungary, H-1121 Költő u. 21., Budapest, Hungary; katonak74@gmail.com \\ * Correspondence: thabang.jeany@gmail.com \\ † Presented at the 1st International Electronic Conference on Biological Diversity, Ecology and Evolution, \\ 15-31 March 2021; Available online: https://bdee2021.sciforum.net/.
}

Citation: Teffo, T.R.; Halpern, B.; Katona, K. Home Range Patterns of the Strictly Protected Caspian Whipsnake (Dolichophis caspius, Gmelin, 1789): A Peri-Urban Population in Vöröskővár, Hungary. 2021, 68, x.

https://doi.org/10.3390/xxxxx

Published: date

Publisher's Note: MDPI stays neutral with regard to jurisdictional claims in published maps and institutional affiliations.

Copyright: (C) 2021 by the authors. Submitted for possible open access publication under the terms and conditions of the Creative Commons Attribution (CC BY) license (http://creativecommons.org/licenses /by/4.0/).
Abstract: Green spaces can exist within and in close proximity to urban environments. These areas readily become habitats to mammals, amphibians, reptiles and other native species that may persist in confined areas within cities. Understanding the expanse of the area in which animals live, or their home range patterns, is important to better understand their ecology. In this study we investigated daily movements, seasonal home ranges and overlap of the Caspian whipsnake (Dolichophis caspius) in a peri-urban area in Budapest, Hungary. We used radio-telemetry to track 5 individual adult snakes within a total area of 125 ha consisting of different microhabitats between 2016 and 2019. Caspian whipsnakes distributed within an area of only 30 ha. We found that they cover on average daily distances of 11-39 $\mathrm{m}$ during vegetation period and less than $5 \mathrm{~m}$ during brumation period. The snakes used home ranges of 6-14 ha during vegetation periods and 0.04-0.28 ha during brumation periods, being the smallest for the underground localities during the brumation period. The Adaptive Kernel method gave the highest, LoCoH-R the smallest home range values. The percentage of home range overlap was found to be smaller during brumation periods when the snakes were underground than during vegetation periods when the snakes were found both, under and above ground. Caspian whipsnakes in Vöröskővár currently have room for movement but it seems that the patches providing shelter (rocky places, burrows, shrubby areas) can limit their distribution, especially during the brumation period. Increased anthropogenic activities, and disturbances mainly in the wintering hiding areas may result in significant threat to the species.

Keywords: movement; radio-telemetry; brumation; reptile; urbanization

Institutional Review Board Statement:

Informed Consent Statement:

Data Availability Statement: 